\title{
Making sense of environmental values: a typology of concepts
}

\author{
$\underline{\text { Marc Tadaki }^{1,2}, \text { Jim Sinner }^{2} \text { and Kai M. A. Chan }}{ }^{3}$
}

\begin{abstract}
Debates about environmental values and valuation are perplexing, in part because these terms are used in vastly different ways in a variety of contexts. For some, quantifying human and ecological values is promoted as a useful technical exercise that can support decision-making. Others spurn environmental valuation, equating it with reducing ethics to numbers or "putting a price tag on nature." We make sense of these complexities by distilling four fundamental concepts of value (and valuation) from across the literature. These four concepts - value as a magnitude of preference, value as contribution to a goal, values as individual priorities, and values as relations - entail fundamentally different approaches to environmental valuation. Two notions of values (as magnitudes of preference or contributions to a goal) are often operationalized in technical tools, including monetary valuation, in which experts tightly structure (and thus limit) citizen participation in decision-making. This kind of valuation, while useful in some contexts, can mask important societal choices as technical judgments. The concept of values as priorities provides a way of describing individuals' priorities and considering how these priorities differ across a wider population. Finally, the concept of values as relations is generally used to foster deliberative forms of civic participation, but this tends to leave unresolved the final translation of civic meanings for decisionmakers. We argue that all forms of valuation - even those that are technical tools - constitute technologies of participation, and that values practitioners should consider themselves more as reflexive facilitators than objective experts who represent the public interest. We thus encourage debate about environmental values to pivot away from theoretical gridlock and toward a concern with citizen empowerment and environmental democracy.
\end{abstract}

Key Words: democracy; ecosystem services; environmental assessment; environmental valuation; participatory methods; politics of knowledge

\section{INTRODUCTION}

Human and ecological "values" have become powerful concepts in environmental management. References to values can be found in contexts ranging from environmental research to management plans and policies. At the global scale, The Economics of Ecosystems and Biodiversity project has three core principles of recognizing, demonstrating, and capturing the value of nature in decision-making (see Kumar 2010). Similarly, the International Science-Policy Platform on Biodiversity and Ecosystem Services has built its conceptual framework on values and the valuation of nature (Diaz et al. 2015). At the national level, the first objective of the United Kingdom's recent National Ecosystem Assessment was to assess "the state and value of the UK's natural environment" (UK National Ecosystem Assessment 2011:3). Across the world in New Zealand, a recent national policy directs local councils to specify freshwater limits based on "local and national values" (New Zealand Government 2014:4).

While this language may reflect an emerging consensus that formalizing "values" should become a cornerstone of environmental policy and management, there is no corresponding consensus about what values are or which approaches to understanding values are useful and legitimate in particular settings. There is now a huge array of approaches to documenting and analyzing human and ecological values, and these approaches come with their own concepts, assumptions, and limitations. While we may be witnessing a turn toward governing through environmental values, it is not yet clear which concepts of value should do the governing.

We synthesize critical academic insights about environmental values concepts to help practitioners and researchers reflect upon what kinds of environmental values assessments might be appropriate in particular settings, and why. We present a typology of values concepts that helps make sense of the diversity of approaches used in the applied environmental values and valuation literature. Rather than generating a typology based on theories, disciplines, or methods, we distinguish four distinct "conceptual approaches" that may include combinations of disciplinary theories and methodologies. Since environmental values assessments in practice tend to contain a mix-and-match of theoretical and methodological inspirations, we contend that conceptual approaches provide a more meaningful and practical way into these debates.

We begin with a brief overview of the literature on environmental values, noting that important critical insights have become buried in theoretical polemics. We then present a typology of four conceptual approaches to documenting and analyzing human and ecological values to support environmental decision-making. We interrogate these concepts and the participatory mechanisms underpinning these approaches in order to support researchers and practitioners to be more transparent about the strengths, limitations, and utility of different kinds of values assessments. We contend that while there are situations in which each conceptual approach may be useful, this does not mean that "anything goes." Specific values concepts and their use have implications for the degree and form of participation by local community members, experts, and environmental managers. We suggest that applied environmental values research can be understood as "technologies of participation," to emphasize how values research acts to structure and frame the participation of community and expert actors in the decision-making process. Value-based environmental decision-making should thus be built on a normative commitment to fostering diverse (or at least distinctly plural) forms of participation by experts and community.

${ }^{1}$ Department of Geography, University of British Columbia, ${ }^{2}$ Cawthron Institute, New Zealand, ${ }^{3}$ Institute for Resources, Environment and Sustainability, University of British Columbia 


\section{VALUES AND ENVIRONMENTAL MANAGEMENT}

Environmental decisions affect people in diverse ways. A new property development or environmental policy, for example, may alter certain people's access to an environment and directly affect their economic livelihoods. Changes may also be more than economic in the sense that peoples' ways of life are fundamentally altered, such that they cannot pursue activities and develop relationships that they see as constitutive of a "good life" (Chan et al. 2016). Concepts of value and values provide tools that researchers and practitioners can use to help categorize, measure, and understand these diverse human-environment relations.

Empirical research on environmental values generally seeks to represent particular aspects of human-environment relationships in ways that can inform environmental decision-making (Ives and Kendal 2014, Jones et al. 2016, Wallace et al. 2016). Research on environmental values can take many forms. Studies might seek to document people's personal priorities (or human values [see Hicks et al. 2015]), with an aim of considering how these priorities and preferences vary across space and social groups. Alternatively, ecological and social values could be treated as residing "out there" in the environment, able to be mapped and modeled across a landscape by experts, with an aim of identifying those places and processes of strategic significance for planning and conservation goals (Boon and Freeman 2009, Bryan et al. 2010). Or in a qualitative vein, values research may seek to document the socio-cultural meanings of ecosystems through narrative accounts and open-ended conversations (Gould et al. 2015).

Across this diversity of values applications, the concepts of value used and their methods of description and analysis differ. A significant (if often unspoken) problem confronting environmental practitioners lies in the choice of concepts and associated approaches for describing and analyzing values. If values are accepted as a useful way to acquire and organize environmental knowledge, what are the implications of adopting one conceptual approach over another?

It is incumbent upon scholars to develop pragmatic criteria and frameworks that can aid practitioners in making sense of how particular concepts and approaches may help achieve social and environmental objectives. For example, Kallis et al. (2013) have suggested that rather than staking ideological positions for or against specific approaches (in their case, monetary valuation), scholars and practitioners should instead consider how environmental valuation applications generate outcomes relating to (1) environmental quality, (2) distributive justice, (3) maintenance of plural value-articulating institutions, and (4) commodification of the environment. In a similar vein, Turnhout et al. (2013) suggest that research on environmental values should (1) consider a diversity of human relations with ecosystems, (2) draw on and build upon already existing and place-based socialnatural relationships, and (3) refrain from instituting single measures of people-environment relationships.

We add to these conversations by focusing on how different values approaches enable and structure civic participation in environmental decision-making. In the next section, we present a typology of four concepts of value that are prominent across the literature on environmental values. Our aim is to connect the concepts used with their related methods and practical aspects of application. We then proceed to explore how different concepts of value structure the participation of different actors in environmental decision-making. We propose that recognizing values applications as "technologies of participation" can provide a normative lens with which to evaluate ethical and democratic trade-offs of different approaches.

\section{A TYPOLOGY OF APPROACHES TO VALUES}

Governments and environmental managers are increasingly embracing values language and thinking, but they operationalize these concepts in diverse ways (and with very different implications). We propose a typology of values concepts and applications that makes explicit these concepts of value/s and their methodological and political implications.

The typology emerged through an iterative engagement with environmental practitioners in New Zealand. A review of the literature on values in environmental policy was conducted in 2010, and was refined through a series of workshops with environmental policy practitioners in local and central government in New Zealand (Berkett et al. 2013, Sinner et al. 2014, Tadaki and Sinner 2014). Through this process, we identified four distinct concepts of value/s that characterize much applied work on values for environmental management. We do not claim that the typology is comprehensive or exclusive, only that it presents practically coherent groupings that help make sense of how different concepts act to structure and delimit citizen involvement in decision-making. We introduce each concept along with its associated assumptions and democratic implications.

\section{Value as a magnitude of preference}

The concept of value (singular) is often used to refer to "how much" an individual or group prefers or needs something; e.g., "the value of water." Farber et al. (2002:379) define value as selfinterest: "value is based on want satisfaction, pleasure or utility goals." Practically speaking, value here refers to a magnitude of preference that a human subject expresses for a particular environmental outcome relative to something else. For example, it makes sense to talk about the value of river restoration (an environmental outcome) for Individual A or Community B relative to some nonrestoration option. Or one could ask how much an individual or community values a particular level of water purification as an ecosystem service.

The use of this concept is most prominent in the economic tradition of monetary valuation. Here, analysts create hypothetical markets for an ecological function or component in order to estimate how much it is worth. This can be done in at least three ways (Daily et al. 2000, Freeman et al. 2014). First, hypothetical markets can be proposed through surveys or interviews, and respondents can be asked directly or indirectly how much they would be willing to pay for an environmental outcome. These are referred to as stated preference methods because they involve participants stating their willingness to pay rather than actually paying. Second, existing economic data can be used to estimate how much utility (preference satisfaction) can be attributed to an ecological function or component. This is achieved by estimating how much an ecological function or component might fetch in a market if it were commodified. For example, the recreational value of a free-entry national park might be estimated using the cost of travel to that park. This is a revealed 
preference approach because it relies on the actual behaviors of consumers rather than on their stated intentions. Third, ecosystems and their functions can be considered as inputs to the economic production process, and the price of substitutes for these inputs can be used to estimate the monetary value of ecosystems. For instance, since the ecosystem service of water purification has existing market-priced substitutes, its value is equated to the cost of the cheapest alternative.

While the value-as-magnitude concept is employed mainly through economic applications, it is not limited to them. There is a range of other methods that seek to elicit stakeholders' preferences for particular environmental places or states through nonmonetary metrics. For example, approaches such as participatory mapping of stated preferences (Brown and Raymond 2014), ranking, and multicriteria analysis (Lennox et al. 2011, Sinner et al. 2014) also rely on eliciting individuals' preferences for one alternative over another.

By approaching value as a magnitude of preference, a number of (contestable) calculations become conceivable. First, the concept implies a kind of commensurability that enables both comparison between and aggregation across individuals. For example, if Jim pays $\$ 100$ for a kayaking trip, and Marc pays $\$ 40$ for fishing in the same river, the aggregate value of these two experiences is $\$ 140$; this could be compared with how much could be obtained from the river water if used for irrigation. Second, value-asmagnitude implies that preferences for the "whole" can be broken down into preferences for component parts. For example, preferences for restoring parts of a river can be estimated through methods such as discrete choice experiments (see, for example, Freeman et al. 2014). Here, estimated preferences for River Outcome A can be compared to preferences for River Outcome $\mathrm{B}$, and the difference in preference magnitudes is assumed to reflect the difference in environmental outcome. A third possible calculation is "benefit transfer": value estimates from one place (composed of people and environments) can be translated to another context to estimate the value of another place (Richardson et al. 2015). This calculation assumes that human preferences are stable across space and that differences between environments (environmental outcomes) are equivalent.

While this value-as-magnitude concept has great appeal for managers, it has been heavily critiqued in various contexts. Sagoff (1998) argued that soliciting human preferences for hypothetical environmental outcomes draws on individual self-interest when decisions should be based on "public good" rationalities (see also Kenter et al. 2015). By seeking to maximize individual preference satisfaction, decision-makers may be neglecting their role in ensuring a fair process and a just distribution of environmental outcomes. For example, building a neighborhood park can be justified on grounds of distributive justice as well as for its aggregate use value. Critics contend that the measurement and aggregation of preferences often ends up substituting individual self-interest for an open and inclusive dialogue about who should gain and lose from particular environmental decisions, and why (Vatn 2009, Kenter et al. 2015).

Use of the value-as-magnitude concept can involve the participation of small groups (as in multicriteria analysis) through to large samples of a population (as in economic surveys). Often, in traditional surveys, citizen participation is constrained in advance by the analyst, who (1) constructs the alternatives that a participant may choose from, and (2) frames the question as the expression of a magnitude of preference (e.g., whether by ranking or willingness to pay). Thus, citizens can participate only by expressing their magnitude of preference for a preselected set of options. They cannot express a preference for an environmental "outcome" that is beyond the stated scope of the analysis, nor can a participant express and discuss the reasons for their preferences (O'Neill and Spash 2000). In traditional survey methods then, participants are asked to "fill in the box" and cannot critique the appropriateness, fairness, or framing of the questions being posed to them, except perhaps in comment boxes, whose contents are generally not used in the formal analysis. Over the last two decades, there has been significant interest in ways to democratize monetary (or preference-based) valuation. This can be done by creating deliberative forums early in the valuation process, where small groups of experts and citizens discuss how preference-based questions should be asked and analyzed (Spash 2007, Lienhoop et al. 2015).

\section{Value as a contribution to a goal}

The singular concept of value can also be articulated as "the contribution of an action or object to user-specified goals, objectives or conditions" (Farber et al. 2002:375). Whereas the previous concept measures the contribution of an environmental state to the satisfaction of human preferences, this concept measures the contribution of an environmental state to externally defined "goals" that can be specified and modeled by experts (Costanza 2000). For example, in the natural sciences, one can talk about the "biodiversity value" of a land use type, or the "conservation value" of a particular river (e.g., Kremen and Ostfeld 2005, Boon and Freeman 2009). In the applied social sciences, it may also make sense to talk about the "recreation value," "tourism value," or "aesthetic value" of a particular environment, where these values are modeled by experts rather than elicited from citizens.

This value-as-contribution concept involves two generic steps for operationalization. The first step is to select the social or ecological goal to be evaluated, which effectively bounds the analysis by allowing certain ecological components in and excluding others (Tadaki et al. 2015). The second step involves the specification of the goal in terms of metrics (and sometimes thresholds), so that a particular environment (or part of an environment) can be represented as a metric contributing to realizing that goal. For example, biodiversity as a goal could be assessed using metrics of species composition, rarity, and richness (Margules and Pressey 2000, O'Keeffe and Uys 2000). Different ecosystems or land use scenarios could be compared according to how much they contribute to realizing the goal of biodiversity according to these metrics (Kremen and Ostfeld 2005).

While value-as-contribution is most prominently operationalized in the natural sciences (e.g., biophysical modeling of ecosystem services), it is also frequently used in environmental planning and management fields to assess "social" goals (Tadaki and Sinner 2014). For example, a New Zealand planning tool called the River Values Assessment System (Hughey 2013) uses small expert groups to evaluate rivers' contributions to a range of values (social goals), such as swimming, native fish, or irrigation. Each of these goals has been selected (bounded) and then specified by an expert 
group. The value of a river for swimming, for example, is turned into a linear function (akin to "production functions," as per Daily et al. 2000) of social and biophysical attributes of a river, such as water clarity, water depth, and the number of swimmers per year. Internationally, many ecosystem service approaches also use this value-as-contribution concept, which involves selecting a number of "services" (i.e., goals), and then modeling them across a landscape, using social and biophysical indicators (Luck et al. 2009).

Other prominent "social values" methods in the international literature, such as quantitative participatory mapping, also involve the value-as-contribution concept. In participatory mapping, participants may be invited to assign relative importance to different spatial areas or ecological features in order to produce maps of "hot spots" of cultural and ecological significance, or to indicate areas where there is compatibility between particular social and/or ecological goals (see Plieninger et al. 2013, Brown and Raymond 2014).

Decisions about (1) appropriate and meaningful societal goals (i.e., bounding), and (2) particular metrics and functions (i.e., measuring) are "political" in that the particular goals chosen and their measurement will have distributive implications for whose interests are realized in environmental decision-making. With respect to bounding, the source and nature of the societal goal need to be articulated. Often it is experts who decide the goals and metrics for measuring social and ecological value (Tadaki and Sinner 2014), which risks producing goals that are not actually aligned with the nuanced aspirations of the community to be governed (Daw et al. 2011, Pröpper and Haupts 2014). Even the selection of scientific indicators with which to measure ecological values can involve disagreement. For example, how conservation value is operationalized through specific metrics has implications for which management interventions are deemed necessary in order to realize the objective (Karp et al. 2015). There may be agreement that conservation is a desirable societal goal, but the specific ways in which it is measured has consequences with potential winners and losers (Tadaki et al. 2015).

In practice, there is scope to facilitate participation through the practices of bounding and measuring. Prior to modeling social and environmental values by experts, the selection and specification of social goals can involve community stakeholders through workshops, public forums, and surveys. The potential moments of participation can be understood as (1) defining and justifying social goals, and (2) developing ways of measuring the attainment of these goals. This process of bounding social aspirations into goals can potentially even be turned into an inclusive and deliberative exercise that is open to a wide range of voices and styles of communicating (Raymond et al. 2014).

\section{Values as individual priorities}

The concept of values as individual priorities is closely linked to the discipline of psychology, in which "human values are conceptualized as consisting of a relatively small number of core ideas or cognitions present in every society about desirable endstates of existence and desirable modes of behavior instrumental to their attainment" (Rokeach 1979:49). Unlike the two previous values concepts, here value resides within individuals as the structure of their priorities rather than value as referring to the importance of a particular environmental object. Simply speaking, this assumes that human individuals possess core priorities (values) that drive all human action. These core priorities are presumed to be distributed differently across individuals, and the task for the analyst is to map the distribution of priorities within individuals and across the population (Schwartz 1992).

In environmental management, this values-as-priorities concept finds expression in attempts to identify patterns of priorities within "the public" or affected communities, and consideration of what this means for representative or inclusive decisionmaking (Dietz et al. 2005, Ives and Kendal 2014, Hicks et al. 2015, Wallace et al. 2016). Often this takes the form of structured surveys, where participants are provided with a list of generic "value items" (i.e., individual priorities, such as doing well in one's career, spending time with family, protecting nature) and are asked to rate the importance of each item to them personally (see Schwartz 1992). Based on psychological or sociological theory, people can then be classified according to the similarity of their priorities. This concept can be used in a descriptive sense to examine the distribution of priorities within and across human populations, and it can also be used in an explanatory sense, for instance when values-as-priorities are linked to motivations for pro-environmental actions (e.g., Dietz et al. 2005, Jones et al. 2016).

Scholars have often used these methods to demonstrate and evaluate the representational "gap" between the makers and subjects of policy. This generally involves mapping the values of a human community in order to make claims about which people's priorities are being represented (or not) in environmental decision-making. This requires characterization of the value-patterns within a particular community, as well as a comparison of those value-patterns with policy and/or other decision-making bodies. For example, Seymour et al. (2011) surveyed local residents, regional water stakeholders, and managers in rural Australia about environmental management priorities. The researchers listed a range of environmental (e.g., bird habitat), social (e.g., peaceful place to be), and economic (e. g., irrigation water) goals, and asked respondents to indicate how important each of these items was to them (on a 1-5 scale). Seymour et al. (2011) observed that urban and rural residents often (and surprisingly) share patterns of personal priorities, but that these value patterns were significantly different from those of regional natural resource managers and interest-based communities (such as farmers). The researchers concluded that if managers' decisions are allied more closely to the priorities of environmental groups than of residents, this raises questions about democratic representation in decision-making (see also Maybery et al. 2005).

Vugteveen et al. (2010) used a different method to a similar effect. Their method, Q-methodology, involved presenting participants with a series of sample statements that reflected different discourses (political story lines) relating to Dutch water policy. Participants positioned these statements into a normal distribution curve, where the $\mathrm{X}$ axis reflected a spectrum from "least accordance" to "most accordance" with their personal viewpoint. Through statistical clustering, Vugteveen et al. (2010) identified five distinct value orientations (holists, technocrats, 
producers, accountable managers, and environmentalists), and suggested that each value orientation warrants representation in decision-making exercises.

While these two examples are local in scale, the values-as-priorities concept can also be operationalized through national-scale surveys of public perceptions of environmental change (Hughey et al. 2013) and surveys that attempt to link social position (e.g., demographics, political ideology) with perceptions of environmental risk and responsibility (Leiserowitz 2006, Corner et al. 2014). In addition, values-as-priorities can be used to explain the motivations behind human behavior, and specifically proenvironmental (or anti-environmental) behaviors. For example, scholars and practitioners may analyze the distributions of values-as-priorities to help develop and promote proenvironmental actions, by appealing to those individual priorities that are most likely to motivate action among target groups (Hicks et al. 2015, Jones et al. 2016).

Applications of values-as-priorities face two challenges. One is that the value items used in generic surveys are often unrelated or only obliquely related to specific environmental management problems. For example, the 58 survey items used by Hicks et al. (2015) cover a range of topics from family to career to community, and while the survey has been tested and refined in the psychological literature, the 58 items are not necessarily "fit for purpose" for environmental management. It is assumed that such surveys capture all or the most relevant core values driving individuals' interests and behavior. In reality, places have unique environmental languages, histories, conflicts, and institutions, and generic values surveys can only scratch the surface of these issues, and possibly even misrepresent them (Norton and Hannon 1997, O’Neill et al. 2008).

The second and related challenge is that the goals (or value items) used in surveys are nearly always selected by experts, which means that these experts define the axes upon which humans' aspirations are compared. Some scholars argue that a pyramid of biological needs can act as a universal framework for ordering human goals (Maslow 1943, Wallace 2007), whereas others create distinctions such as environmental/social/economic or ethical/cognitive/ aesthetic when seeking to group people's priorities (Vugteveen et al. 2010, Seymour et al. 2011). There is always a risk that analystframed value items will "miss the point" in a particular setting (Tadaki et al. 2015).

The forms of participation enabled through these applications vary in scale and scope. In terms of scale, analysts often seek statistically representative samples through surveys, whether as mail-out surveys or a large number of structured interviews (e.g., Dietz et al. 2005, Corner et al. 2014, Hicks et al. 2015). While the sample size can be modest in the case of small communities (Vugteveen et al. 2010, Seymour et al. 2011), representativeness can be attained insofar as participation reflects wider community composition, even if statistical significance may not be possible (Raymond et al.2014). In terms of scope, the value items are often either generated directly by experts or drawn from public materials and assembled by experts.

\section{Values as relations}

Values can also be understood as notions of appropriate or desired relationships between people and nature. O'Neill et al.
(2008:1) provocatively declare that "There are no such things as values. There are rather the various ways in which individuals, processes and places matter, our various modes of relating to them, and the various considerations that enter into our deliberations about action." For these authors, the values of a place do not reside in humans as core drivers of action, nor are they external and universal objects of investigation with intrinsic worth. Rather, values should be understood as being composed of the spatially and historically contingent relationships and meanings that connect people to their environments and ecosystems.

Instead of inviting human subjects to choose between predefined responses (e.g., I prefer option A over option B), the values-asrelations concept has generally been used to draw attention to the many and diverse relationships through which people derive meaning from ecosystems and their processes (e.g., Klain et al. 2014). Chan et al. (2016) refer to "relational values" as a way of emphasizing that people's relationships to environments can contribute to pursuit of a "good life" in ways that challenge and exceed instrumental (social and economic) and intrinsic (ecological) values. In this view, values research is not solely about how much people prefer one scenario over another (magnitude of preference), or about optimally organizing the pursuit of selected social goals. It is also about what different ecosystems and processes mean to different people (O'Neill et al. 2008). Such relations might be articulated in the forms of stories, myths, metaphors, ethical roles (e.g., stewardship), social practices, and ontological frameworks (West 2005, Stephenson 2008, Chan et al. 2011, Euzen and Morehouse 2011, Raymond et al. 2013, Satterfield et al. 2013, Pröpper and Haupts 2014). The concept of relational values is thoroughly place-based, finding parallels with the "sense of place" literature that has developed over the past three decades (Nassauer 1995, Williams 2014). Here, we might think of a sense of place as an outcome that emerges from a constellation of values-as-relations.

Use of this values-as-relations concept generally emphasizes two things. First, it involves more open-ended conversations about how and why environments matter to people (Gould et al. 2015). It does not narrowly specify which social-environmental relationships are legitimate or meaningful for a given context; instead, it seeks to paint a rich picture of environmental meanings and ethical roles. For example, there often exists a range of motivations for an activity such as fishing (e.g., meanings and roles relating to ritual, self-sustenance, family, fun), and if an environmental policy is designed to increase the "fishing value" of an environment by increasing the number of visiting fishers per year, this may produce crowding, reduced access for locals, and a loss of connection between locals and that environment (e.g., Klain et al. 2014). Simply asking how much people prefer one outcome over another can ignore the multiple meanings and outcomes of social and environmental change, and effectively privilege a narrow way of relating to the environment.

Second, thinking about values-as-relations positions economic theories of value as merely one type of relationship among many (Gibbs 2010, Chan et al. 2012b, Raymond et al. 2013). Applications of the relational concept emphasize the rich contextual meanings of environments to local human subjects 
rather than preboxing those meanings through an a priori analytical framework (Stephenson 2008, Klain et al. 2014). This focus on local meanings (rather than analytical meanings) suggests that different types of political representation may be warranted (Dryzek and Niemeyer 2008, Raymond et al. 2014). For example, within the farming community, there are elements whose primary focus is profitability, while others are concerned about food security or sustaining family farming as a way of life. So, rather than providing for representation of (assumed homogeneous) interest groups, values-as-relations suggests that a diversity of "ways that environments matter" should be represented in any valuation exercise (Satterfield et al. 2013, Turnhout et al. 2013).

In practice, applications of the values-as-relations concept tend to (1) seek a qualitative richness/diversity of environmental meanings, and (2) attend to the specific environment in consideration. In pursuit of qualitative richness, these approaches generally use open-ended qualitative methods such as interviews and discourse analysis, and draw on a range of primary and secondary material (such as oral histories and documentary evidence). An emphasis on environmental specificity is achieved by focusing on people's relationships with specific environments (though relations such as ethical roles can be applied to more than one environment), sometimes involving technologies such as public participation geographic information systems (PPGIS) (Brown and Kytta 2014) or participatory mapping as props (Klain et al. 2014). Maps and spatial tools can help participants identify, discuss, and relate the meanings of different environments and situate them in space for purposes of environmental management (Bryan et al. 2010).

Those operationalizing the values-as-relations concept face a significant challenge relating to the translation of meaning. Translation refers to the abstraction of meaning from one context (where interpretation is stabilized by local social relations and conversational setting) and its transference into another context, where the originating social relations cannot influence or stabilize interpretations (see West 2005). In this sense, the environmental meanings articulated in one conversation (say an interview) are typically reinterpreted to connect with the vocabularies, concepts, and worldviews of the receiving audience, including decisionmakers. For example, Jackson (2006) observed how complex indigenous environmental meanings were simplified and translated by researchers and policy-makers in order to be unthreatening and submissive to existing colonial power relations. Similarly, Forero (2012:32) described a state-sanctioned PPGIS exercise with indigenous communities in Brazil as an "instrument of cultural assimilation" that sought to capture local knowledge for appropriation by the state. Great care must be taken to build trust with communities, and to communicate clearly the nature of the decision-making exercise, its boundaries, and the risks that come with sharing information (Chan et al. 2012a).

Diverse authors are seeking to bring more than economic "ways that environments matter" onto the applied environmental values agenda and into decision-making processes more generally (Gibbs 2010, Chan et al. 2012a, Turnhout et al. 2013). This stems from both a discontent with the exclusion of marginal voices from decision-making and a frustration that even when marginal voices are included, people's relationships with their environments are often translated in ways that are not appropriate or consensual (Satterfield et al. 2013). While the extent of participation in values-as-relations applications can range from individual interviews to focus groups or public forums, they are distinguished from other approaches by an intent to let environmental stakeholders articulate their own ways that environments matter. However, since translation remains fundamental to this process, practitioners still have significant responsibility for how they elicit and report on these relationships (Jackson 2006).

\section{COMPARING APPROACHES TO VALUES: TECHNOLOGIES OF PARTICIPATION?}

The typology above elaborates conceptual and methodological aspects of four prominent values concepts, and emphasizes how each approach provides distinct mechanisms for citizens and experts to participate in decision-making. Table 1 summarizes this information, along with examples and methods for each type of approach. Here, we briefly discuss what this typology adds to the literature, why values methods should be understood as a technologies of participation, and why mixing and matching values methods needs to proceed thoughtfully.

\section{Utility of a typology}

The comparative analysis facilitated by our typology focuses on the embedded assumptions and relevant critiques of the four approaches, and the different forms of participation they enable. We can now situate this typology among the typologies of values and valuation approaches offered by others. Raymond et al. (2014) compared instrumental and deliberative approaches to values and valuation, and examined how each approach involves distinct perspectives on rationality, different processes of value elicitation, particular types of representativeness, and various degrees of decision-maker involvement. In contrast, Lienhoop et al. (2015) surveyed a range of deliberative methods for monetary valuation, and produced a checklist that indicates which methods are suitable for particular settings. Against this backdrop, our typology adds insight in two ways.

While Raymond et al. (2014) compare two broad families of "instrumental" and "deliberative" approaches to values and valuation, the typology presented here distinguishes four concepts of value. This enables a more nuanced comparison of conceptual approaches, thereby helping to explicate what is being measured in a given values application and why. For example, in Table 1, we demonstrate how participatory mapping can be used in three different ways, each drawing on a different conceptual approach to values. The typology encourages practitioners to consider which approach to participatory mapping is appropriate for their project, or conversely, to reflect on the assumptions and democratic implications embedded in the approach that they have already chosen to use. The typology thus helps reveal what is otherwise obscured by simply describing the method as participatory mapping and categorizing the values as instrumental.

The same can be said of a wide body of approaches pursued under the banner of ecosystem services. While ecosystem services research is unified through its focus on understanding the links between ecological structure/function and human well-being, there are many concepts and methods that can be used within this - from economic valuation methods to modeling pollination 
Table 1. Key features and forms of participation for four concepts of value, with commonly associated methods and disciplines.

\begin{tabular}{|c|c|c|c|c|}
\hline & $\begin{array}{l}\text { Value as magnitude of } \\
\text { preference }\end{array}$ & Value as contribution to a goal & Values as individual priorities & Values as relations \\
\hline \multirow[t]{2}{*}{ Illustration } & $\begin{array}{l}\text { Person A prefers the river } \\
\text { in state } \mathrm{X} \text { more than state } \\
\text { Y. }\end{array}$ & $\begin{array}{l}\text { Expert A determines that River } \\
\text { X has higher fish habitat value } \\
\text { than River Y. }\end{array}$ & $\begin{array}{l}\text { Priorities of farmers in } \\
\text { Community } \mathrm{Z} \text { can be } \\
\text { categorized as profit-seeking, } \\
\text { lifestyle, or traditional. Each }\end{array}$ & $\begin{array}{l}\text { Person A values River } \mathrm{X} \text { in part to } \\
\text { fish in the same place that her } \\
\text { family has fished for generations. }\end{array}$ \\
\hline & $\begin{array}{l}\text { Person A would be willing } \\
\text { to pay } \$ 100 \text { to achieve state } \\
\mathrm{X} \text { and } \$ 50 \text { to achieve state } \\
\mathrm{Y} \text {. }\end{array}$ & $\begin{array}{l}\text { Expert A determines that River } \\
\text { X has lower swimming value } \\
\text { than River Y. }\end{array}$ & $\begin{array}{l}\text { category is linked to different } \\
\text { behaviors and demographics. }\end{array}$ & $\begin{array}{l}\text { Person B values the irrigation she } \\
\text { derives from River Y to provide } \\
\text { food for her family and community. }\end{array}$ \\
\hline $\begin{array}{l}\text { Participatory } \\
\text { mapping example }\end{array}$ & $\begin{array}{l}\text { Respondents distribute a } \\
\text { fixed number of tokens to } \\
\text { indicate how much they } \\
\text { care about various sites. } \\
\text { Tokens can be summed } \\
\text { across individuals and then } \\
\text { the importance of different } \\
\text { places is compared, } \\
\text { without need to } \\
\text { understand why the places } \\
\text { are important to different } \\
\text { people. }\end{array}$ & $\begin{array}{l}\text { Respondents distribute a fixed } \\
\text { number of tokens to indicate } \\
\text { how important different sites } \\
\text { are for a specific purpose, such } \\
\text { bird-watching, kayaking, or } \\
\text { food gathering. This produces } \\
\text { ranking of the most important } \\
\text { sites for each purpose. }\end{array}$ & $\begin{array}{l}\text { Not applicable-mapping } \\
\text { locates values in the } \\
\text { environment, whereas } \\
\text { priorities are statements about } \\
\text { generalized personal goals } \\
\text { and are not place-specific. }\end{array}$ & $\begin{array}{l}\text { Respondents are presented with a } \\
\text { map and asked to identify places } \\
\text { that matter to them and then } \\
\text { explain why. This yields stories } \\
\text { about relations between people and } \\
\text { places. }\end{array}$ \\
\hline Source of "value" & Human & Environment & Human & $\begin{array}{l}\text { Relationships between humans and } \\
\text { environment }\end{array}$ \\
\hline Assumptions & $\begin{array}{l}\text { Peoples' preferences differ } \\
\text { only in magnitude and can } \\
\text { be abstracted, compared, } \\
\text { and aggregated. }\end{array}$ & $\begin{array}{l}\text { The value of an environment } \\
\text { can be modeled as a function of } \\
\text { its objectively measurable } \\
\text { attributes. }\end{array}$ & $\begin{array}{l}\text { There is a small and knowable } \\
\text { number of perspectives on an } \\
\text { issue, and those perspectives } \\
\text { can be explained as products } \\
\text { of core human priorities. }\end{array}$ & $\begin{array}{l}\text { Social-environmental relationships } \\
\text { are contextual and cannot or } \\
\text { should not be made equivalent to } \\
\text { other relationships or priorities. } \\
\text { They have to be described, } \\
\text { analyzed, and evaluated in context. }\end{array}$ \\
\hline $\begin{array}{l}\text { Form of } \\
\text { participation }\end{array}$ & $\begin{array}{l}\text { Participant can indicate } \\
\text { "how much" they prefer } \\
\text { environmental states } \\
\text { defined by an analyst. }\end{array}$ & $\begin{array}{l}\text { Experts estimate the } \\
\text { contribution of different } \\
\text { landscapes to specific goals. } \\
\text { Nonexperts can help select } \\
\text { goals and criteria for } \\
\text { measurement. }\end{array}$ & $\begin{array}{l}\text { Participant can indicate } \\
\text { strength of agreement with } \\
\text { pregiven statements to map } \\
\text { their "value orientation." }\end{array}$ & $\begin{array}{l}\text { Participants can use their own } \\
\text { language to express how } \\
\text { environments matter to them and } \\
\text { why they are worthy of protection. }\end{array}$ \\
\hline Methods & $\begin{array}{l}\text { Nonmarket monetary } \\
\text { valuation } \\
\text { Deliberative monetary } \\
\text { valuation } \\
\text { Multicriteria decision } \\
\text { analysis } \\
\text { Structured decision- } \\
\text { making } \\
\text { Participatory mapping } \\
\text { (quantitative) }\end{array}$ & $\begin{array}{l}\text { Expert-driven environmental } \\
\text { assessment } \\
\text { Ecosystem service modeling } \\
\text { Conservation prioritization } \\
\text { Participatory mapping } \\
\text { (quantitative) }\end{array}$ & $\begin{array}{l}\text { Universal value item surveys } \\
\text { (e.g., Schwartz values survey) } \\
\text { Interviews } \\
\text { Q method } \\
\text { Discourse analysis }\end{array}$ & $\begin{array}{l}\text { Interviews } \\
\text { Focus groups } \\
\text { Deliberative workshops } \\
\text { Discourse analysis } \\
\text { Ethnography } \\
\text { Participatory action research } \\
\text { Participatory mapping (qualitative) } \\
\text { Textual analysis }\end{array}$ \\
\hline $\begin{array}{l}\text { Disciplines } \\
\text { (indicative) }\end{array}$ & $\begin{array}{l}\text { Economics } \\
\text { Decision theory }\end{array}$ & $\begin{array}{l}\text { Applied ecology } \\
\text { Conservation biology } \\
\text { Landscape architecture }\end{array}$ & $\begin{array}{l}\text { Psychology } \\
\text { Quantitative sociology } \\
\text { Marketing } \\
\text { Communication sciences }\end{array}$ & $\begin{array}{l}\text { Anthropology } \\
\text { Environmental sociology } \\
\text { Geography } \\
\text { Cultural studies } \\
\text { History }\end{array}$ \\
\hline
\end{tabular}

services to mapping cultural values. Our typology distinguishes between these methods to reveal for practitioners what is at stake when selecting and constructing a particular project.

In addition, the typology uses practical conceptual approaches to support practitioners in finding their place among a huge variety of methods and disciplinary theories. For example, rather than analyzing economic valuation on its own, we use the concept of value-as-magnitude to include other forms of ranking and preference articulation, for which the same critiques and assumptions apply: they make preferences commensurable, aggregable, and transferable across space (and populations). What is important is not so much the specific discipline (e.g., economics) but the qualities of the concept being used. Practitioners cannot be expected to become disciplinary theorists in psychology, economics, conservation ecology, and the like. However, they can be supported to recognize the characteristics of the conceptual approach they are using (or deciding upon).

\section{Technologies of participation?}

For practitioners facing a confusing array of conceptual approaches to environmental values, we propose that thinking 
about values methodologies as "technologies of participation" can highlight normative concerns about equity and power in environmental decision-making (see also Carnoye and Lopes 2015). All types of applied values research involve structuring the (non)participation of particular local actors and experts in decision-making processes. Whichever approach is used, particular roles are implied for experts and publics.

The value-as-contribution concept can be used with natural science data (e.g., indicators of ecosystem function) or social data (e.g., recreational use statistics). Whatever type of data is used, this conceptual approach relies on bounding particular social goals and then measuring the extent to which some aspect of the environment contributes to realizing those goals. Citizens could be involved in the selection of social goals through focus groups (Raymond et al. 2014), but more often these goals are selected based on the scientific literature or expert judgment (Daw et al. 2011). The extent to which the selected goals are meaningful to local communities is an open question that deserves asking (Tadaki et al. 2015).

While the value-as-magnitude and values-as-priorities concepts typically involve communication between researchers and local environmental actors, this is often constrained and sometimes absent. Value-as-magnitude applications predefine the rationality context within which citizens participate (Vatn 2009). Here experts, sometimes informed by focus groups, preselect a number of environmental states that participants must choose among, as well as the units with which participants must register their preference (value-as-magnitude). Similarly, when using values-aspriorities concepts, analysts prescribe the list of value statements whose personal importance is ranked by participants. Both of these values concepts facilitate a type of participation of local actors in decision-making, but their participation is constrained by the categories and assumptions of the analysis.

In contrast, the values-as-relations concept has often been explicitly mobilized to support more egalitarian power relations between analysts and community participants (Satterfield et al. 2013). This is predicated on a theoretical and ethical shift toward thinking about values through local languages and categories rather than starting with or imposing "top down" frameworks of value (Norton and Hannon 1997, Klain et al. 2014, Tadaki et al. 2015). Of course, there are still the risks and responsibilities involved in translation. Qualitative and open-ended approaches to canvassing diverse ways that environments matter involve processes of coding and interpretation that can translate people's claims and expressions into new frameworks of thought and action (e.g., environmental management). While the problems of translation are ever-present, they can at least be made explicit.

\section{Choosing values methods...in context}

Different concepts of value focus on different things. Some focus on values within humans, and some treat values as objective and "out there" in the environment. Some align well with existing economic and decision-making ideologies, while others may challenge these. Since different conceptual approaches do not actually measure the same thing (Martín-López et al. 2014), one cannot simply reject one approach as worse than another. There are diverse contexts within which environmental values research might make a difference. While we may have ethical reservations about some applications of the value-as-magnitude concept, for example, this does not mean that its use could never result in improved environmental outcomes or social justice (Kallis et al. 2013). Each values concept can have a legitimate place in environmental politics, but this is not to say that anything goes, or that methods should be chosen to fit a predetermined outcome that has been judged by the analyst to be socially desirable. While it is beyond our scope to prescribe when particular approaches should be used, we offer four points that may help sensitize thinking around the selection of approaches in a particular context.

First, different conceptual approaches may be warranted at different points in the decision-making process based on the scope of the decision being made. If we think about values-as-relations as generally "opening up" participation in decision-making and value-as-magnitude as generally closing it down, one could argue for the former preceding the latter temporally (Raymond et al. 2014). We concur with Martín-López et al. (2014), who argue that values researchers have a responsibility to connect "within scope" decision outcomes to effects that might be considered "out of scope." For example, what is initially thought to be an economic decision (value-as-magnitude) might affect people's holistic livelihoods (values-as-relations) as well as biodiversity (value-ascontribution) in ways that are not initially understood.

Second, environmental values research can be used to support a range of ideological positions. Norgaard (2010) notes that monetary value framings of ecosystem services have found strategic uptake because of their alignment with neoliberal economic growth agendas (see also Gómez-Baggethun and RuizPeréz 2011). Similarly, value-as-magnitude approaches may find ideological alignment with bureaucrats who want to solve difficult distributive decisions by referring to some numerical and "objective" weighting of the public interest. In such a situation, the value-as-magnitude concept serves as a tool to aggregate the public interest, often ignoring distributional impacts. In contrast, values-as-relations approaches do not generally result in commensurable statements that can be weighed up and optimized in a technical fashion; they make trade-offs more complex by including (rather than ignoring) multiple types of socialenvironment relations. In this sense, values-as-relations approaches can provide a pluralist counterweight to economically focused agendas and languages (Raymond et al. 2013).

Third, while different values concepts have their own implications for participation, these are not necessarily predetermined. For example, the value-as-contribution concept can be used to support expert-driven approaches to environmental decisionmaking, but it can also be operationalized through more open and deliberative means to include community stakeholders at various points throughout the process (Raymond et al. 2014, Lopes and Videira 2016). Deliberative workshops involving stakeholders and experts can be used at the start of a process to frame up which social goals should be modeled scientifically, how, and why. Similarly, even economic valuation can be made more deliberative (Spash 2007).

A final point about mixing and matching methods is that values concepts and language need to be situated within place and history. Values concepts and applications structure how we interpret conflict as well as how we perceive ourselves as political subjects, such as citizens or consumers. Ioris (2012) and Williams 
(2014) propose that valuation exercises are always "positioned" in that they reflect partial perspectives on an issue and always reflect some social groups' interests more than others. The languages and concepts we use to describe and analyze ecosystems and humans have specific historical meanings in particular places, and this comes with political baggage as well as opportunities. For example, in places with high stakes struggles against the enclosure and commodification of natural resources, using monetary valuation can reinforce unequal power relations between communities and economic elites (Ioris 2011).

Our typology assists practitioners in considering which approach to values might be appropriate for a particular project, given the assumptions and democratic implications that are embedded in different approaches. Ultimately, every case involves its own historical and geographical constraints and opportunities - it is up to practitioners to build specific arguments to justify a particular approach or mix of approaches in a given setting.

\section{CONCLUSION}

Different concepts of environmental values structure citizen participation in decision-making in different ways. Some exercises invite citizens to indicate a magnitude of preference for a particular outcome, and others ask how much a series of generic value items matter to them personally. Some applications ask participants how ecosystems matter to their livelihood and wellbeing, whereas others involve experts rather than citizens in order to quantify scientifically the value of ecological processes. Attempts to draw together this diversity of approaches under a single banner such as ecosystem services have tended to obscure more than enlighten. We developed this typology as a way to make meaningful distinctions between concepts and to consider their practical effects.

At the very least, we hope this can help practitioners identify different values concepts as they appear in multiple guises. Whether we encounter values concepts through disciplinary paradigms (e.g., psychology, economics), interdisciplinary frameworks (such as ecosystem services), or methods such as participatory mapping, practitioners can now move to identify the relevant concepts in use and consider what these might mean in the wider context of the environmental politics of a place.

The differences between these concepts are not merely theoretical. They produce different effects in the real world. Values applications create channels for local actors to have a say about their priorities or express their preferences for different pathways of development. Values applications create platforms for experts to make claims about the value of the environment, and can thus give experts a privileged role, as well as significant responsibility.

Environmental values applications can be fruitfully understood as technologies of participation. By thinking about how environmental values applications facilitate different forms of participation (for different social groups), perhaps new concepts, frameworks, and hybridizations might become thinkable. Whose participation should be sought for a particular environmental decision, through which technology, and why? It is not sufficient to answer these questions through reference to a theoretical construct or paradigm. We do not just need to account for the content of our theories; we must also account for the effects of our practices.
Responses to this article can be read online at: http://www.ecologyandsociety.org/issues/responses. php/8999

\begin{abstract}
Acknowledgments:
This work has been supported through the Freshwater Values, Monitoring and Outcomes project (C09X1003), funded by the Ministry of Business, Innovation and Employment. We thank our colleagues from this project and from the Regional Council Forum who have challenged and enriched our thinking over the course of this project. Thoughtful and constructive reviewer comments significantly strengthened this article.
\end{abstract}

\section{LITERATURE CITED}

Berkett, N., I. Challenger, J. Sinner, and M. Tadaki. 2013. Values, collaborative processes and indicators for freshwater planning. Report No. 2353. Cawthron Institute, Nelson, New Zealand. [online] URL: http://www.landcareresearch.co.nz/publications/ researchpubs/Berkett_2013 Values_collaborative_process.pdf

Boon, P. J., and M. Freeman. 2009. Methods for assessing the conservation value of rivers. Pages 142-165 in P. J. Boon and C. M. Pringle, editors. Assessing the conservation value of fresh waters: an international perspective. Cambridge University Press, Cambridge, UK.

Brown, G., and M. Kytta. 2014. Key issues and research priorities for public participation GIS (PPGIS): a synthesis based on empirical research. Applied Geography 46:122-136. http://dx.doi. org/10.1016/j.apgeog.2013.11.004

Brown, G., and C. M. Raymond. 2014. Methods for identifying land use conflict potential using participatory mapping. Landscape and Urban Planning 122:196-208. http://dx.doi. org/10.1016/j.landurbplan.2013.11.007

Bryan, B. A., C. M. Raymond, N. D. Crossman, and D. H. Macdonald. 2010. Targeting the management of ecosystem services based on social values: where, what, and how? Landscape and Urban Planning 97:111-122. http://dx.doi.org/10.1016/j. landurbplan.2010.05.002

Carnoye, L., and R. Lopes. 2015. Participatory environmental valuation: a comparative analysis of four case studies. Sustainability 7:9823-9845. http://dx.doi.org/10.3390/su7089823

Chan, K. M. A., P. Balvanera, K. Benessaiah, M. Chapman, S. Díaz, E. Gómez-Baggethun, R. Gould, N. Hannahs, K. Jax, S. Klain, G. W. Luck, B. Martín-López, B. Muraca, B. Norton, K. Ott, U. Pascual, T. Satterfield, M. Tadaki, J. Taggart, and N. Turner. 2016. Why protect nature? Rethinking values and the environment. Proceedings of the National Academy of Sciences of the United States of America 113(6):1462-1465. http://dx.doi. org/10.1073/pnas.1525002113

Chan, K. M. A., J. Goldstein, T. Satterfield, N. Hannahs, K. Kikiloi, R. Naidoo, N. Vadeboncoeur, and U. Woodside. 2011. Cultural services and non-use values. Pages 206-228 in P. M. Kareiva, H. Tallis, T. H. Ricketts, G. C. Daily, and S. Polasky, editors. Natural capital: theory and practice of mapping ecosystem 
services. Oxford University Press, New York, USA. http://dx.doi. org/10.1093/acprof:oso/9780199588992.003.0012

Chan, K. M. A., A. D. Guerry, P. Balvanera, S. Klain, T. Satterfield, X. Basurto, A. Bostrom, R. Chuenpagdee, R. Gould, B. S. Halpern, N. Hannahs, J. Levine, B. Norton, M. Ruckelshaus, R. Russell, J. Tam, and U. Woodside. 2012a. Where are cultural and social in ecosystem services? A framework for constructive engagement. BioScience 62(8):744-756. http://dx.doi.org/10.1525/ bio.2012.62.8.7

Chan, K. M. A., T. Satterfield, and J. Goldstein. $2012 b$. Rethinking ecosystem services to better address and navigate cultural values. Ecological Economics 74:8-18. http://dx.doi. org/10.1016/j.ecolecon.2011.11.011

Corner, A., E. Markowitz, and N. Pidgeon. 2014. Public engagement with climate change: the role of human values. WIREs Climate Change 5(3):411-422. http://dx.doi.org/10.1002/ wec. 269

Costanza, R. 2000. Social goals and the valuation of ecosystem services. Ecosystems 3:4-10. http://dx.doi.org/10.1007/s100210000002

Daily, G. C., T. Soderqvist, S. Aniyar, K. Arrow, P. Dasgupta, P. R. Ehrlich, C. Folke, A. Jansson, B.-O. Jansson, N. Kautsky, S. Levin, J. Lubchenco, K.-G. Maler, D. Simpson, D. Starrett, D. Tilman, and B. Walker. 2000. The value of nature and the nature of value. Science 289:395-396. http://dx.doi.org/10.1126/ $\underline{\text { science. } 289.5478 .395}$

Daw, T., K. Brown, S. Rosendo, and R. Pomeroy. 2011. Applying the ecosystem services concept to poverty alleviation: the need to disaggregate human well-being. Environmental Conservation 38 (4):370-379. http://dx.doi.org/10.1017/s0376892911000506

Diaz, S., S. Demissew, J. Carabias, C. Joly, M. Lonsdale, N. Ash, A. Larigauderie, J. R. Adhikari, S. Arico, A. Baldi, A. Bartuska, I. A. Baste, A. Bilgin, E. Brondizio, K. M. A. Chan, V. E. Figueroa, A. Duraiappah, M. Fischer, R. Hill, T. Koetz, P. Leadley, P. Lyver, G. M. Mace, B. Martin-Lopez, M. Okumura, D. Pacheco, U. Pascual, E. S. Perez, B. Reyers, E. Roth, O. Saito, R. J. Scholes, N. Sharma, H. Tallis, R. Thaman, R. Watson, T. Yahara, Z. A. Hamid, C. Akosim, Y. Al-Hafedh, R. Allahverdiyev, E. Amankwah, S. T. Asah, Z. Asfaw, G. Bartus, A. L. Brooks, J. Caillaux, G. Dalle, D. Darnaedi, A. Driver, G. Erpul, P. EscobarEyzaguirre, P. Failler, A. M. M. Fouda, B. Fu, H. Gundimeda, S. Hashimoto, F. Homer, S. Lavorel, G. Lichtenstein, W. A. Mala, W. Mandivenyi, P. Matczak, C. Mbizvo, M. Mehrdadi, J. P. Metzger, J. B. Mikissa, H. Moller, H. A. Mooney, P. Mumby, H. Nagendra, C. Nesshover, A. A. Oteng-Yeboah, G. Pataki, M. Roue, J. Rubis, M. Schultz, P. Smith, R. Sumaila, K. Takeuchi, S. Thomas, M. Verma, Y. Yeo-Chang, and D. Zlatanova. 2015. The IPBES Conceptual Framework - connecting nature and people. Current Opinion in Environmental Sustainability 14:1-16. http:// dx.doi.org/10.1016/j.cosust.2014.11.002

Dietz, T., A. Fitzgerald, and R. Shwom. 2005. Environmental values. Annual Review of Environment and Resources 30:335-372. http://dx.doi.org/10.1146/annurev.energy.30.050504.144444

Dryzek, J. S., and S. Niemeyer. 2008. Discursive representation. American Political Science Review 102 (4):481-493. http://dx.doi. org/10.1017/s0003055408080325
Euzen, A., and B. Morehouse. 2011. Water: what values? Policy and Society 30:237-247. http://dx.doi.org/10.1016/j.polsoc.2011.10.005

Farber, S. C., R. Costanza, and M. A. Wilson. 2002. Economic and ecological concepts for valuing ecosystem services. Ecological Economics 41:375-392. http://dx.doi.org/10.1016/S0921-8009 (02)00088-5

Forero, O. 2012. Mapping in epistemological translation, revising the critique of GIS (Geographical Information Systems) as an instrument of cultural assimilation. Human Geography 5(3):3249.

Freeman, A. M., J. A. Herriges, and C. L. Kling. 2014. The measurement of environmental and resource values: theory and methods. RFF Press, Abingdon, UK.

Gibbs, L. M. 2010. "A beautiful soaking rain": environmental value and water beyond Eurocentrism. Environment and Planning D: Society and Space 28:363-378. http://dx.doi.org/10.1068/ $\underline{\mathrm{d} 9207}$

Gómez-Baggethun, E., and M. Ruiz-Pérez. 2011. Economic valuation and the commodification of ecosystem services. Progress in Physical Geography 35(5):613-628. http://dx.doi. org/10.1177/0309133311421708

Gould, R. K., S. C. Klain, N. M. Ardoin, T. Satterfield, U. Woodside, N. Hannahs, G. C. Daily, and K. M. A. Chan. 2015. A protocol for eliciting nonmaterial values through a cultural ecosystem services frame. Conservation Biology 29(2):575-586. http://dx.doi.org/10.1111/cobi.12407

Hicks, C. C., J. E. Cinner, N. Stoeckl, and T. R. McClanahan. 2015. Linking ecosystem services and human-values theory. Conservation Biology 29(5):1471-1480. http://dx.doi.org/10.1111/ cobi. 12550

Hughey, K. F. D. 2013. Development and application of the River Values Assessment System for ranking New Zealand river values. Water Resources Management 27:2013-2017. http://dx.doi. org/10.1007/s11269-013-0269-4

Hughey, K. F. D., G. N. Kerr, and R. Cullen. 2013. Public perceptions of New Zealand's environment: 2013. EOS Ecology, Christchurch, New Zealand.

Ioris, A. A. R. 2011. Values, meanings, and positionalities: the controversial valuation of water in Rio de Janeiro. Environment and Planning C: Government and Policy 29:872-888. http://dx.doi. org/10.1068/c10134

Ioris, A. A. R. 2012. The positioned construction of water values: pluralism, positionality and praxis. Environmental Values 21:143162. http://dx.doi.org/10.3197/096327112X13303670567251

Ives, C. D., and D. Kendal. 2014. The role of social values in the management of ecological systems. Journal of Environmental Management 144:67-72. http://dx.doi.org/10.1016/j.jenvman.2014.05.013

Jackson, S. 2006. Compartmentalising culture: the articulation and consideration of indigenous values in water resource management. Australian Geographer 37(1):19-31. http://dx.doi. org/10.1080/00049180500511947

Jones, N. A., S. Shaw, H. Ross, K. Witt, and B. Pinner. 2016. The study of human values in understanding and managing social- 
ecological systems. Ecology and Society 21(1):15. http://dx.doi. org/10.5751/ES-07977-210115

Kallis, G., E. Gómez-Baggethun, and C. Zografos. 2013. To value or not to value? That is not the question. Ecological Economics 94:97-105. http://dx.doi.org/10.1016/j.ecolecon.2013.07.002

Karp, D. S., C. D. Mendenhall, E. Callaway, L. O. Frishkoff, P. M. Kareiva, P. R. Ehrlich, and G. C. Daily. 2015. Confronting and resolving competing values behind conservation objectives. Proceedings of the National Academy of Sciences of the United States of America 112(35):11132-11137. http://dx.doi.org/10.1073/ pnas. 1504788112

Kenter, J. O., L. O’Brien, N. Hockley, N. Ravenscroft, I. Fazey, K. N. Irvine, M. S. Reed, M. Christie, E. Brady, R. Bryce, A. Church, N. Cooper, A. Davies, A. Evely, M. Everard, R. Fish, J. A. Fisher, N. Jobstvogt, C. Molloy, J. Orchard-Webb, S. Ranger, M. Ryan, V. Watson, and S. Williams. 2015. What are shared and social values of ecosystems? Ecological Economics 111:86-99. http://dx.doi.org/10.1016/j.ecolecon.2015.01.006

Klain, S. C., T. A. Satterfield, and K. M. A. Chan. 2014. What matters and why? Ecosystem services and their bundled qualities. Ecological Economics 107:310-320. http://dx.doi.org/10.1016/j. ecolecon.2014.09.003

Kremen, C., and R. S. Ostfeld. 2005. A call to ecologists: measuring, analyzing, and managing ecosystem services. Frontiers in Ecology and the Environment 3(10):540-548. http:// dx.doi.org/10.1890/1540-9295(2005)003[0540:actema]2.0.co;2

Kumar, P., editor. 2010. The economics of ecosystems and biodiversity: ecological and economic foundations. Earthscan, London, UK.

Leiserowitz, A. 2006. Climate change risk perception and policy preferences: the role of affect, imagery, and values. Climatic Change 77:45-72. http://dx.doi.org/10.1007/s10584-006-9059-9

Lennox, J., W. Proctor, and S. Russell. 2011. Structuring stakeholder participation in New Zealand's water resource governance. Ecological Economics 70:1381-1394. http://dx.doi. org/10.1016/j.ecolecon.2011.02.015

Lienhoop, N., B. Bartkowski, and B. Hansjurgens. 2015. Informing biodiversity policy: the role of economic valuation, deliberative institutions and deliberative monetary valuation. Environmental Science \& Policy 54:522-532. http://dx.doi. org/10.1016/i.envsci.2015.01.007

Lopes, R., and N. Videira. 2016. A collaborative approach for scoping ecosystem services with stakeholders: the case of Arrabida Natural Park. Environmental Management 58:323-342. http://dx.doi.org/10.1007/s00267-016-0711-5

Luck, G. W., K. M. A. Chan, and J. P. Fay. 2009. Protecting ecosystem services and biodiversity in the world's watersheds. Conservation Letters 2:179-188. http://dx.doi.org/10.1111/ j.1755-263X.2009.00064.X

Margules, C. R., and R. L. Pressey. 2000. Systematic conservation planning. Nature 405:243-253. http://dx.doi.org/10.1038/35012251

Martín-López, B., E. Gómez-Baggethun, M. García-Llorente, and C. Montes. 2014. Trade-offs across value-domains in ecosystem services assessment. Ecological Indicators 37:220-228. http://dx.doi.org/10.1016/j.ecolind.2013.03.003

Maslow, A. H. 1943. A theory of human motivation. Psychological Review 50(4):370-396. http://dx.doi.org/10.1037/ $\underline{\mathrm{h} 0054346}$

Maybery, D., L. Crase, and C. Gullifer. 2005. Categorising farming values as economic, conservation and lifestyle. Journal of Economic Psychology 26(1):59-72. http://dx.doi.org/10.1016/j. joep.2003.10.001

Nassauer, J. I. 1995. Culture and changing landscape structure. Landscape Ecology 10(4):229-237. http://dx.doi.org/10.1007/ $\underline{\mathrm{BF} 00129257}$

New Zealand Government. 2014. National Policy Statement for Freshwater Management 2014. [online] URL: http://www.mfe. govt.nz/sites/default/files/media/Fresh $\% 20$ water/nps-freshwatermanagement-jul-14.pdf

Norgaard, R. B. 2010. Ecosystem services: from eye-opening metaphor to complexity blinder. Ecological Economics 69:12191227. http://dx.doi.org/10.1016/j.ecolecon.2009.11.009

Norton, B. G., and B. Hannon. 1997. Environmental values: a place-based theory. Environmental Ethics 19:227-245. http://dx. doi.org/10.5840/enviroethics199719313

O'Keeffe, J. H., and M. Uys. 2000. The role of classification in the conservation of rivers. Pages 445-458 in P. J. Boon, B. R. Davies and G. E. Petts, editors. Global perspectives on river conservation: science, policy and practice. Wiley, Chichester, UK.

O’Neill, J., A. Holland, and A. Light. 2008. Environmental values. Routledge, London, UK.

O'Neill, J., and C. L. Spash. 2000. Conceptions of value in environmental decision-making. Environmental Values 9:521536. http://dx.doi.org/10.3197/096327100129342191

Plieninger, T., S. Dijks, E. Oteros-Rozas, and C. Bieling. 2013. Assessing, mapping, and quantifying cultural ecosystem services at community level. Land Use Policy 33:118-129. http://dx.doi. org/10.1016/j.landusepol.2012.12.013

Pröpper, M., and F. Haupts. 2014. The culturality of ecosystem services. Emphasizing process and transformation. Ecological Economics 108:28-35. http://dx.doi.org/10.1016/j.ecolecon.2014.09.023

Raymond, C. M., J. O. Kenter, T. Plieninger, N. J. Turner, and K. A. Alexander. 2014. Comparing instrumental and deliberative paradigms underpinning the assessment of social values for cultural ecosystem services. Ecological Economics 107:145-156. http://dx.doi.org/10.1016/j.ecolecon.2014.07.033

Raymond, C. M., G. G. Singh, K. Benessaiah, J. R. Bernhardt, J. Levine, H. Nelson, N. J. Turner, B. Norton, J. Tam, and K. M. A. Chan. 2013. Ecosystem services and beyond: using multiple metaphors to understand human-environment relationships. BioScience 63(7):536-546. http://dx.doi.org/10.1525/bio.2013.63.7.7

Richardson, L., J. Loomis, T. Kroeger, and F. Casey. 2015. The role of benefit transfer in ecosystem service valuation. Ecological Economics 115:51-58. http://dx.doi.org/10.1016/j.ecolecon.2014.02.018 
Rokeach, M. 1979. From individual to institutional values: with special reference to the values of science. Pages 47-70 in M. Rokeach, editor. Understanding human values: individual and societal. The Free Press, New York, USA.

Sagoff, M. 1998. Aggregation and deliberation in valuing environmental public goods: a look beyond contingent pricing. Ecological Economics 24:213-230. http://dx.doi.org/10.1016/ $\underline{\text { S0921-8009(97)00144-4 }}$

Satterfield, T., R. Gregory, S. Klain, M. Roberts, and K. M. Chan. 2013. Culture, intangibles and metrics in environmental management. Journal of Environmental Management 117:103114. http://dx.doi.org/10.1016/j.jenvman.2012.11.033

Schwartz, S. H. 1992. Universals in the content and structure of values: theoretical advances and empirical tests in 20 countries. Advances in Experimental Social Psychology 25:1-65. http://dx. doi.org/10.1016/S0065-2601(08)60281-6

Seymour, E., A. Curtis, D. J. Pannell, A. Roberts, and C. Allan. 2011. Same river, different values and why it matters. Ecological Management \& Restoration 12(3):207-213. http://dx.doi. org/10.1111/j.1442-8903.2011.00605.X

Sinner, J., O. Samarasinge, and M. Newton. 2014. Tools for working with freshwater values. Report No. 2569. Cawthron Institute, Nelson, New Zealand. [online] URL: http://www. cawthron.org.nz/media new/publications/pdf/2015 01/ $\underline{\text { CR2569Tools for working with freshwater values.pdf }}$

Spash, C. L. 2007. Deliberative monetary valuation (DMV): issues in combining economic and political processes to value environmental change. Ecological Economics 63:690-699. http:// dx.doi.org/10.1016/j.ecolecon.2007.02.014

Stephenson, J. 2008. The cultural values model: an integrated approach to values in landscapes. Landscape and Urban Planning 84:127-139. http://dx.doi.org/10.1016/j.landurbplan.2007.07.003

Tadaki, M., W. Allen, and J. Sinner. 2015. Revealing ecological processes or imposing social rationalities? The politics of bounding and measuring ecosystem services. Ecological Economics 118:168-176. http://dx.doi.org/10.1016/j.ecolecon.2015.07.015

Tadaki, M., and J. Sinner. 2014. Measure, model, optimise: understanding reductionist concepts of value in freshwater governance. Geoforum 51:140-151. http://dx.doi.org/10.1016/j. geoforum.2013.11.001

Turnhout, E., C. Waterton, K. Neves, and M. Buizer. 2013. Rethinking biodiversity: from goods and services to "living with". Conservation Letters 6:154-161. http://dx.doi.org/10.1111/ j.1755-263X.2012.00307.X

UK National Ecosystem Assessment. 2011. UK National Ecosystem Assessment: technical report. UNEP-WCMC, Cambridge, UK.

Vatn, A. 2009. An institutional analysis of methods for environmental appraisal. Ecological Economics 68 (8-9):22072215. http://dx.doi.org/10.1016/j.ecolecon.2009.04.005

Vugteveen, P., H. J. R. Lenders, J. L. A. Devilee, R. S. E. W. Leuven, R. J. H. M. van der Veeren, M. A. Wiering, and A. J. Hendriks. 2010. Stakeholder value orientations in water management. Society \& Natural Resources 23 (9):805-821. http:// dx.doi.org/10.1080/08941920903496952

Wallace, K. J. 2007. Classification of ecosystem services: problems and solutions. Biological Conservation 139:235-246. http://dx. doi.org/10.1016/j.biocon.2007.07.015

Wallace, K. J., C. Wagner, and M. J. Smith. 2016. Eliciting human values for conservation planning and decisions: a global issue. Journal of Environmental Management 170:160-168. http://dx. doi.org/10.1016/j.jenvman.2015.12.036

West, P. 2005. Translation, value, and space: theorizing an ethnographic and engaged environmental anthropology. American Anthropologist 107(4):632-342. http://dx.doi.org/10.1525/ aa.2005.107.4.632

Williams, D. R. 2014. Making sense of 'place': reflections on pluralism and positionality in place research. Landscape and Urban Planning 131:74-82. http://dx.doi.org/10.1016/j. landurbplan.2014.08.002 